\title{
Towards a Class-centred Approach to EFL Teaching in the Palestinian Context
}

\author{
Adnan I. Abu Ayyash \\ The Arab American University, Jenin, Palestine \\ E-mail: adnan_aysh@hotmail.com
}

Received: June 9, 2011

Accepted: June 30, 2011

Published: December 1, 2011

doi:10.5539/elt.v4n4p65

URL: http://dx.doi.org/10.5539/elt.v4n4p65

\begin{abstract}
The teaching article attempts to highlight the significance of introducing a class-centred approach (henceforth CCA) to L2 teaching in the Palestinian context. Additionally, it aims to pinpoint that experienced teachers can make their teaching strategies more motivating and more communicative, through intertwining their learners' pedagogical and social demands. It is centered on the EFL teachers' everyday behaviours in a language classroom. It tries to precisely give an explanation and a definition of the concept of (CCA) and its implication in classroom language learning In addition, the article investigates the theoretical framework that underlie the CCA to teaching. In order to provide an overview of the present teaching preferences in L2 classroom conducted by EFL teachers at home, a questionnaire has been distributed to a sample population of EFL teachers from a Palestinian university. Meanwhile, the article tries to justify the need and the appropriateness of CCA to language teaching, with special focus on the Palestinian context. Alongside discussing and analyzing the questionnaire results, the article also makes use of major findings reached by many studies in this respect. Ultimately, it concludes discussion by confirming that language teachers' success in meeting and intertwining the learners' socio-pedagogic needs help EFL teachers cultivate and create a non-threatening classroom environment in which learners interact readily in the target language.
\end{abstract}

Keywords: Class-centred approach, Setting, Pedagogical needs, Social wants

\section{Introduction}

English as a foreign language (EFL) has long been the centre of attention of educationalists, linguists, EFL teachers and learners. This can be noticed in the large number of studies geared towards research in L2, EFL approaches and difficulties encountered by learners (Hamdan 1994). Like too many EFL learners, Palestinian students face serious problems in English learning at almost every level all through their schooling. (IIEP, 1997). Low proficiency in English among Palestinian learners is evident in their inability to communicate in English following many years of learning. (For example, ELC-AAUJ Placement Exam results 2005-2009)

In his classroom-centred approach, Allwright (1986) who argues that learning a language is 'hardly' an easy task, reviews some of teachers' classroom habits which influence EFL learning experience. Senior $(2002 ; 2006 \mathrm{a} ; 2006 \mathrm{~b})$ focuses on the importance of identifying a framework for understanding the basis of the teachers' everyday behaviour in classroom, on which she believes that it underlies the theoretical assumptions language teachers base their everyday classroom practices and decisions on.

Language teachers agree that no two of their classes are identical- even when the two are given the same course. In some classes teachers approach teaching pleasantly, while in others, things are quite the opposite. Hadfield (1997) agrees that language teachers' main concern is related to the atmosphere of the classroom and components of the class group. This article is going to address the concept of class-centered approach, its teaching and learning implications, its realization and materialization in our classrooms at home situation, and its appropriateness in mono-cultural class settings as observed in the Palestinian context.

On the one hand, it is the concern of this article to review the language teachers' willingness to create and maintain a learning community within the classroom. On the other hand, it highlights EFL teachers' teaching preferences inside language classroom at home, and aims to pinpoint that experienced teachers can make their teaching strategies more motivating, constructive and communicative. The presentation stresses that our EFL teachers need to work on a real compromise between the learners' pedagogical and social demands. Once language teachers succeed in intertwining these needs, they can foster and cultivate a class-centred approach (CCA) in our teaching career, and, eventually, they will be able to create a non-threatening classroom environment in which learners interact readily in the target 
language.

One may argue that the socio-pedagogic consideration is likely to work well in multi-national classes where learners come from different cultural background; still, learners from the same cultural setting - as the case in the Palestinian context - have great opportunities to improve their language if teachers approach teaching under a framework that successfully balances between social and pedagogic priorities.

It is true that this trend in L2 is not new; nevertheless, it is an essential assumption that our teachers can exploit effectively and efficiently in their ongoing efforts they exert to help learners overcome difficulties in L2 learning. Rivers (1992) argue that successful teachers are those who understand their learners' different needs.

The article overviews a group of Palestinian EFL teachers' everyday behaviour preferences in their classrooms. For this purpose, a questionnaire has been distributed to EFL teachers at the Arab American University-Jenin (AAUJ) as a sample of the target population (see Appendix 1). The results show the present practices in classroom and the wanted ones as priorities expressed by the teachers.

Finally, the article concludes the discussion with suggesting certain aspects of classroom language teaching- among too many, and ways through which language teachers teach and manage their classes at the same time.

\section{Objectives}

The article attempts to highlight the significance of introducing a class-centered approach to L2 teaching in the Palestinian context. However, the study is not necessarily confined to certain EFL target group in terms of their qualifications, classes they teach or experience. As the study is centered on the everyday behaviour in a language classroom, it precisely attempts to:

- delineate the concept of (CCA) and investigate its theoretical and practical implications

- review EFL teaching preferences and practices in L2 classroom.

- examine the appropriateness of the approach at home situation.

- look into EFL teachers' need to identify their learners' socio-pedagogical demands.

In their attempt to create a non-threatening classroom teaching environment, EFL teachers try hectically to experiment, and eventually, employ methods that 'best' fulfill the objectives of EFL leaning at home situation. With the introduction of a class-centred approach into their classes, EFL teachers are likely to 'shift' from their traditional role as knowledgeable resource for learners into other roles that not less significant than this, and even go beyond it. They can help in creating a learning community- classroom learners- in which the members wok together in a cohesive way that each finds a role in this learning community.

\section{The Concept of Class-centred Approach: Theoretical Framework}

Allwright (1986) argues that language learning is 'hardly' an easy task. In his classroom-centred research, Allwright $(1983 ; 1986)$ "tries to understand the processes that happen in classroom and why and how they take place that way." (1983: 191).

The critical issue here is not the teaching methods that language teachers employ in class, neither it is the classroom management in terms of discipline or physical setting. It is an issue that goes beyond that, a situation in which we try to give responses to questions that concern both language teachers and learners: what behaviours and practices do teachers perform in class? Why do teachers find some classes easier to teach than others? Why do teachers believe that no two classes are identical while they have the same teacher with the same course syllabus? What makes language learning more difficult? What experience, other than pedagogical, makes learning more effective? How can experienced teachers deal with a non-unified individuals as a unifed unit or a learning community that share more than they differ?

In her answer to some of these queries, Senior $(1997 ; 2002 ; 2006 \mathrm{a} ; 2006 \mathrm{~b}$; 2008) claims that the introduction of a (CCA) into our classes may respond partly to the issue of effective learning. This approach does not simply mean creating a non-threatening class eniveronment; rather it calls for intertwinig learners' learning wants with their socail demands. More precisely, Senior (2002) believes "....that teachers are sensitive to the social needs of their class groups, and that their pedagogically and socially-oriented behaviours are closely intertwined." (2002: 399)

There is no doubt that some EFL teachers are class-centred ones consciously or subconsciously. They pay attention to their learners' needs, wants and demands that go too far beyond the learning and language tasks in their classes. These teachers are the ones who know their stuff, who can also develop a relationship with their learners individually and collectively. These teachers are best described by Finch, 2002 as "agents of social change" in the classroom. How we can put this role in a context of humanistic goal is the critical question. 
Rivers (1992) argues that,

"Language teachers must study the language learners in their classes- their ages, their background, their aspirations, their interest, their goals in language learning, their aptitude for language acquisition in a formal setting." (Rivers, 1997: 376) .

Is the (CCA) a proven way to effective learning and efficient teaching? How can classroom-centred research provide a theoretical framework for language teachers? To what extent can intertwining the learners' social needs with their learning experience be of any help in the teaching and learning process? These questions presume that the assumption that efficient teaching and effective learning can result from the introduction of a (CCA) to our classes. Classroom research has shown that pedagogical experience is only one part of the 'complicated' learning process. In summing up her major findings of classroom observations she conducted for different EFL teachers' performance in classes, Senior (2002) believes that there is a correlation between quality of class groups \& quality of teaching/ learning; she concludes that:

Teachers have demonstrated through their everyday classroom behaviour that language teaching is a highly complex business that not only involves teaching effectively, but also attending to the social well-being of their class groups. (2002: 402)

It is true that gathering a group of learners with a teacher in a classroom is going to be complex and full of experiences of the members. (Wright: 2006; Ashour: 2008) Our awareness of this complexity of the individualslearners - may require us to look deeply into these individuals' needs: be social, pedagogical, cognitive or psychological, once we agreed to take teaching as our career.

The ultimate goal of teaching EFL in our context as expressed in the syllabus outlines (see ELC-AAUJ Advanced English syllabus 2009 ) is to enable learners to learn, or, eventually, 'master' the language four skills and sub-skills and to enable them to become skilled and trained on dealing with the language components. With this goal ahead, EFL teachers are exerting endless efforts to fulfill this aim through employing different teaching approaches and other cognitive- functional means that would enhance the achievement of this goal. (Tomasello: 1992).

One major effort teachers may consider is paying close attention to their learners' social needs alongside the pedagogical experience, as the latter is existing in any teaching agenda after all, why not including the former if it motivates and creates a free-stress, friendly and non-threatening context for learning in class. Also, teachers who are class-centred do focus on their learners, how they feel and on how effectively they learn; an assumption that best forms a realization of the learning-centred or learner-centred teaching method, and ultimately, the communicative approach. (Littlewood, 1981).

It is very significant to clarify what connotation social needs of an EFL learner refers to. In the first place, we have to agree that learners are members of a group in a classroom known as learning community. Therefore, it is EFL teachers' concern, as Hadfield (1992) claims, to think of the atmosphere in the classroom and the chemistry of the group than problems of how to teach the language. This assumption calls for dealing with the class as a whole-group unit which requires the participation of each member to the uniqueness, activation techniques and the 'success' of the group. In her feedback on this paper, Senior assumes that "Developing a sense of unity within the class as a whole is the overall goal of the class-centred approach" (Senior's email commenting on this paper, on June $2^{\text {nd }}$, 2011). Tian et al ( 2004) understand that the cohesiveness of the learning group in class means furnishing for the idea of accepting the other, open-mindedness, safe L2 practice, less discipline burden on teachers, individual's self-esteem and success of both the individual learner and the group. It is clear then that these values can be best achieved once challenging and convenient language tasks are given to the target learners of the group.

For example, in teaching paragraph writing, a teacher can brainstorm learners first to agree on a topic for writing. This can be carried out by consensus and voting for a topic. Then groups are formed with a spokesperson and a group reporter for each group. To ensure that learning is taking place, the teacher can sit with each group, discuss, listen and share ideas. The teacher's mindful discussion with the groups is one way of establishing a kind of relationship with the class or the learning community there. Each group presents their product on a board in class, where the different groups share and compare their writings. Evidently, the group work is a main feature of the communicative teaching of English.

Therefore, what makes a 'good' teacher for the learners is dependent on the teacher-learner interpersonal relations that are geared towards fulfilling the pedagogical wants. Sowden (2007) believes that:

"Success as a teacher does not depend on the approach or method that you follow so much as on your integrity as a person and the relationships that you are able to develop in the classroom. The ability to build and maintain human relationships in this way is central to effective teaching”. (2007: 308) 
Peterson (2005) agrees that a relaxing classroom leaning environment takes place when a learner feels that he/she belongs to a group with a caring teacher, and when feeling accepted by other learners.

Finch (2002) and Senior (2006 b) agree that CCA to EFL teaching approach has certain principles that can be viewed as general guidelines for classroom behaviours. They add that teachers are required to enjoy many characteristics that make both learning and teaching effective. Accordingly, teachers are asked to value their learners equally, to ensure there is a variety in activities which are supposed to be effective both socially and pedagogically, to encourage self-confidence without focusing on competence or performance, and reflect a student-centered view of language learning. With these principles in mind, we can furnish for a motivating learning setting that is considered a cornerstone in EFL learning. There is no doubt that some EFL learners do better than others because they are better motivated. Gardner (1991) and Littlewood (1986) argue that such learners will find it difficult to learn a foreign language in a classroom if they have neither instrumental nor integrative motivation.

The way EFL teachers can link their learners' social needs with their learning experiences is an easy task by itself. It is true that experienced teachers are class-centred, as Senior (2006a) mentioned above; still approaching the concept and employing it in class is a critical story.

\section{Teachers' Preferences in Language Classroom}

As this article intends to highlight EFL teachers' attitude and teaching preferences inside language classroom, pinpoint the significance of intertwining their learners' pedagogical and social demands and to urge our EFL teachers to introduce and practice (CCA) in their teaching career, the study target population will be all EFL teachers in the Palestinian universities of the West Bank. The article took a sample population of EFL teachers and teacher assistants at the Arab American University-Jenin (AAUJ). It used a questionnaire-based tool to get first-hand information from EFL teachers on their language classroom behavior preferences and practices. The questionnaire is comprised of three sections that include background information, 13 items and one ranking question. (see Appendix 1).

The questionnaire has been distributed to EFL teachers and teacher assistants who teach English courses and language lab classes at the English Language Center (ELC) at the (AAUJ) in the academic year 2010/2011. The second part of the questionnaire with its 13 items supposedly cover specific aspects of the topic in focus. In their answer to item 6 of the questionnaire (see Table 1), more than half of the teachers (53\%) believes that meeting their learners' learning demands is a priority.

With a percentage of $(27 \%)$ who has no opinion on the same item, one can draw a conclusion that most teachers see pedagogical needs as a main concern. From experience, it is believed that our EFL teachers understand that the ultimate goal of any EFL syllabus is, roughly, to enable learners to acquire language skills and sub-skills, and, therefore, the 'contract' between teachers and learners is leaning/teaching proceedings. Another related consideration of preferring pedagogy is the pressure of time span limit and administrative requirements to abide by a given syllabus outline. Even though these considerations may be justified, again learners need a teacher who, as Senior (2006) puts it, is not only " an expert in their field as a language teacher; but also they want somebody who can actually develop a relationship with them both individually and with the class as a whole." (2006: 400).

Another expression of EFL teachers' focus on pedagogy is seen in the questionnaire item 11 in which (73\%) feels that some of their classes are pedagogically frustrating. Moreover, about $79 \%$ of the teachers ranked their classes pedagogical setting as the most important, and the remaining percentage ranked it second.

A major surprising response is the teachers' uncertainty about the effect of meeting the learner's social needs in helping them overcome teaching obstacles as expressed in item 13, where $53 \%$ has no opinion. This also explains the teachers' opinion on the difficulty to create a homelike learning setting in class which positively reflects on the learners' approaching the class activities in a relaxing atmosphere. More than one third of the teachers agree that it is difficult for them to create a friendly environment in class (item 10), while another third expresses no opinion in this respect. This difficulty may be associated with teaching experience as we find that the majority of teachers who find it easy to set up a friendly class setting is among those with more than 10 years of teaching experience. Also, these findings explain the teachers' ranking of social setting where $60 \%$ of the respondents placed it in the third or fourth place. (see Table 2).

In their answer to the importance of humour in class (item 1), the majority of the teachers- $80 \%$ - believes that employing humour in their classes is a vital aspect in their teaching techniques. It looks that teachers do not consider the sense of humour as part of the learners' social needs, rather they may think of it as an occasional incident for motivating purposes, or as an on-the-spot energizer. 
When more than $86 \%$ of the teachers (item 5) thinks that their learners' cultural backgrounds are non-identical, they agree that they deal with dissimilar individuals-learners- who are culturally different. This leads us to the conclusion that the concept of cultural background is a vague and ambiguous notion for the teachers who could have found as an interchangeable term with learners' prior knowledge or their socioeconomic status. However, this issue is not the concern of this paper. What concerns us here is that most, if not all, our learners share the same cultural background in terms of ethnic group, traditions, norms and socially-oriented behaviour. They are definitely different in their leaning styles, classroom behaviour, and other individual aspects that influence their learning.

Another surprising preference of the teachers' practices in classroom is that $40 \%$ of teachers and another $13 \%$ with no opinion see their classes as individual learners, and not as one unit (item7). This implies that the consideration of the needs of the learning community still ranked second after the individual learner's needs. Apparently, this implication may look promising in terms of approaching learner-centred teaching method which ultimately focuses on the learner (Littlewood, 1983). However, the teachers' previous preference is likely to be viewed as a misleading, unless it is explicitly understood that the individuals are members with different learning abilities who form a cohesive leaning community where each contributes, shares and works in beehive-like environment. (Senior, 2006 a)

The percentage of $73 \%$ is significantly high when teachers expressed their ability to identify their learners' learning needs as seen in (item 4). Again, the teachers must be talking about pedagogical wants, and might be fully dependent on their tuition, observations and teaching experience. If this is the case, the question of identifying the learners' learning needs is subjectively-oriented process that lacks scientific research and objective identification and analysis of these needs.

\section{Class-centered in the Palestinian context: Does it work?}

In one of my Advanced classes in the summer session in 2010, one of the best students expressed a significant point of view about the English course he was attending. He said, "When I do language tasks in this class, I must say that I feel so comfortable as if I'm talking to my father, brothers and sisters at the dining table." Even though this may not be the case with most EFL learners at home situation, this learner with his sincere expression has triggered and ignited an idea that geared me to try to look for an acceptable and precise educational interpretation for a better teaching classroom practices that may go beyond the methods of teaching I have learnt, practiced and tried in my classes.

This assumption leads us to recall what Senior (1997) said about teachers' position in the cohesive group, that they "are both an integral part of their class groups, and in a sense set apart-just as a parent who bonds with a child is both a blood relation and an authority figure". (1997: 4)

In other occasions, other learners would voice other negative views about their roles in a class where they may have mixed feelings of tense, anxiety and pressure. In a podcast interview on the concept of class-centred, Senior (2006 b) stresses that experienced teachers always link pedagogical and social classroom behaviours in a way that both influence and are influenced by the atmosphere of the class. She also states that a major principle in (CCA) requires teachers to "develop rapport with individuals and with the class as a whole." (The podcast interview 2006).

Cehan (2002) believes that teachers try to gear learners towards interaction through establishing a creative discourse by providing continuous classroom social roles tasks that get all learners involved in activities no matter how small the role may be.

Palestinian teachers, in particular EFL ones, may argue that this trend we are calling for- socio-pedagogic consideration- works well in classes with cultural diversity or multicultural background which is likely to be different from the Palestinian context. Nevertheless, learners with similar cultural setting, as in our case, have great opportunities to approach language and learn its skills once a framework that successfully embraces their social and pedagogic priorities. Rivers (1992) argues that successful teachers are those who understand their learners' different needs.

Colibaba (2009) criticizes the teacher who "does not make pedagogical choices which provide cohesion to the class and thereby stimulate the perception of a positive learning environment," because she thinks that the learners in such a class will never reach a satisfying level of communication in the foreign language. (2009: 184)

As Palestinian EFL teachers and their learners are monoculture, and nearly all our learners themselves share the same cultural background, one can assume that establishing friendly ties between the learners and their teachers in classroom is attainable. While it is apparently easier for learners to set up good social relationship within their classmates through language pair-tasks or group ones, teachers are the best people to set as examples for their learners, to show respect to the members of their learning groups, to be good listeners to them, to stand at the same 
distance from each learner, and basically to treat them in a humanistic way. As this behaviour may cultivate a mutual respect between learners and their teacher, and, eventually develop a more motivating atmosphere, a positive pedagogical experience is going to be fostered.

\section{Conclusion}

As the article first introduces the concept of (CCA) to EFL teaching, it should be stated that teachers, particularly the experienced, employ it in classroom in a way or another. However, in order to meet learners' social and pedagogical needs, teachers are urged to objectively do classroom-based research that can give answers to their day-to-day practices in class. The research should target classroom teaching and learning management in an attempt to give explanations for the most effective and efficient practices - other than teaching approaches - that teachers may practice in their classes. For example, teachers can identify and then analyze their learners' learning needs through using a questionnaire that gives first-hand information about their learners' pedagogical background, their past learning experience, their preferred ways of approaching a course. In their analysis of learners' learning needs, teachers, on the one hand, are expected to plan, outline and organize their courses; on the other hand, they get clear ideas that gear them towards appropriate methods of approaching their teaching process. It is through the identification and analysis of the learners' needs, teachers will have to consider the learner's socio-pedagogical demands in their teaching plans. The social demands discussed earlier are best realized in classroom everyday behaviour through teachers' employment of a humanistic teaching context where they cultivate values that foster learner's self-esteem, self-confidence, respect, participatory trend in the learning community (class), sense of belonging, democracy, and equality-oriented practices. However, the present EFL teachers' preferences and classroom behaviours analyzed in the paper indicate that theoretical assumptions that underlie the approach in focus, i.e. CCA to teaching, still need to be spotlighted among EFL teachers at home situation.

\section{Further Studies}

Although the class-centred approach is not a new trend in EFL teaching, much more research is needed in this respect. Both qualitative and quantitative research will provide a more objective framework that can form criteria for teachers to benefit from concerning approaching learners' socio-pedagogical demands. How to practically apply the approach in class needs to be established in a form of guidelines for EFL teachers. These principles can be drawn out from longitudinal research that includes class observations, interviews of both teachers and learners, review of theories on teaching as a humanistic process.

\section{References}

Allwright, D. (1983). Classroom-Centered Research on Language Teaching and Learning: A Brief Historical Overview. TESOL Quarterly, Vol. 17, No. 2, Jun., 1983, 191-204

Allwright, D. (1986). Seven ways of making classroom learning difficult. Prospect, 1986, 2, 50-66

Allwright, D. (1992). Interaction in the language classroom: social problems and pedagogic possibilities. Language teaching in today's world. Proceedings of the 1989 International Symposium on Language Teaching and Learning.

Allwright, D. (1996). Social and pedagogic pressures in the language classroom: the role of socialisation in H. Coleman (ed.).

Ashour, S. (2008). An Alternative Tool for Understanding Life in the Language Classroom, MA dissertation. Exeter: University of Exeter.

Cehan, D. A. (2002). Interpersonal and pedagogical communication: argument for natural communication practices in the Romanian classroom. M.A, School for International Training. Brattleboro, Vermont.

Colibaba, A. C. (2009). Group cohesion in the English language class. SYNERGY, 5, 2, 174-182

Gardner, R. C., \& MacIntyre, P. D. (1991). An instrumental motivation in language study: who says it isn't effective? Studies in Second Language Acquisition, 13, 57-72. http://dx.doi.org/10.1017/S0272263100009724

Hadfield, J. (1992). Classroom Dynamics. Oxford: Oxford University Press.

Littlewood, W. (1981). Communicative Language Teaching: an introduction. Cambridge: Cambridge University Press.

Littllewood, W. (1986). Foreign and Second Language Acquisition. Cambridge, CUP.

Meng Tian, Ester D. Jimena, \& Herwindy Maria Tedjaatmadja. (2007). Integrating Group Cohesiveness Activities in the Syllabus,Assumption University of Thailand. [Online] Available: www.petra.ac.id (January 20, 2011)

Peterson, M. (2005). CREATING A CARING COMMUNITY: Meeting the social and emotional needs of students 
to provide the critical foundation for learning. [Online] Available: www.education.wayne.edu (January 20, 2011)

Rivers, W. M. (1992). Ten principles of interactive language learning and teaching in W. M. Rivers (ed.). Cambridge.

Rivers, W. M. (ed.). (1992). Teaching Languages in College: curriculum and content. Lincolnwood, IL: National Textbook.

Senior, R. (1997). Transforming Language Classes into Bonded Groups. ELT Journal, 51, 1, 3-11. http://dx.doi.org/10.1093/elt/51.1.3

Senior, R. (2002). Class-centred approach to language teaching, ELT Journal, 56(4), 397-403. Copyright Oxford University Press.

Senior, R. In a podcast interview 2006. [Online] Available: www.cambridge.org/elt (December, 2010)

Senior, R. (2006 a). Class-centred teaching is successful teaching in ENGLISH TEACHING professional, 46. [Online] Available: www.etprofessional.com (September 2006)

Senior, R. (2006 b). The Experience of Language Teaching. Cambridge: Cambridge University Press.

Senior, R. (2008). Developing \& sustaining interpersonal connections in language classrooms, a presentation. [Online] Available: www.tesol.org.au (January 20, 2011)

Senior, R. Senior's email commenting on this paper. (June 2, 2011)

Sowden, C. (2007). Culture and the 'good teacher' in the English Language classroom. Oxford journals. ELT Journal, 61, 4, 304-310. http://dx.doi.org/10.1093/elt/ccm049

The Arab American University. English Language Centre Records of English Placement Test 2005- 2010.

The International Institute for Educational Planning (IIEP)-UNESCO-IIEP forum on repetition, 1997.

Wright, T. (2006). Managing classroom life. In S. Gieve, and I. K. Miller (eds.). Cambridge.

Table 1. Percentage of Respondents for each item

\begin{tabular}{|c|c|c|c|c|}
\hline No. & Item & $\frac{\sqrt{2}}{8}$ & $\begin{array}{l}Z \\
Z \\
0 \\
\text { o. } \\
\text { E. } \\
0\end{array}$ & 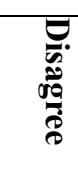 \\
\hline 1 & Humour is an essential part of my classroom teaching techniques. & 80 & 6.7 & 13.3 \\
\hline 2 & My learners' social demands come second priority & 27 & 33 & 40 \\
\hline 3 & My classroom physical setting is my first priority in teaching. & 40 & 20 & 40 \\
\hline 4 & I always manage to identify my learners' learning needs. & 73 & 27 & 0 \\
\hline 5 & My learners have identical cultural background. & 13 & 13 & 86.7 \\
\hline 6 & $\begin{array}{l}\text { Meeting my learners' pedagogical needs is my ultimate goal of } \\
\text { teaching. }\end{array}$ & 53 & 27 & 20 \\
\hline 7 & I consider each of my classes as one unit. & 47 & 13 & 40 \\
\hline 8 & I can easily explain why I feel relaxed when teaching certain classes. & 73 & 0 & 26.7 \\
\hline 9 & $\begin{array}{l}\text { I don't have the same feeling when I teach different classes with the } \\
\text { same level and syllabus. }\end{array}$ & 67 & 13 & 20 \\
\hline 10 & Creating a homelike setting in my classroom is difficult. & 33 & 33 & 33.3 \\
\hline 11 & Some of my classes are pedagogically frustrating. & 73 & 13 & 13.3 \\
\hline 12 & I follow different teaching approaches for similar classes. & 87 & 0 & 13.3 \\
\hline 13 & $\begin{array}{l}\text { Meeting my learners' social demands help me overcome teaching } \\
\text { obstacles. }\end{array}$ & 47 & 53 & 0 \\
\hline
\end{tabular}


Table 2. (questionnaire section 3) Percentage of ranked items in terms of importance

\begin{tabular}{|l|c|c|c|c|}
\hline \multicolumn{1}{|c|}{ Item } & Rank 1 & Rank 2 & Rank 3 & Rank 4 \\
\hline Class physical environment & 20 & 6.6 & 26.6 & 46.6 \\
\hline Class social setting & 20 & 20 & 33.3 & 26.6 \\
\hline Class pedagogical setting & 60 & 26.6 & 6.6 & 6.6 \\
\hline Class cultural background & 6.6 & 46.6 & 26.4 & 20 \\
\hline
\end{tabular}

Note: No. 1 is the most important, 2 is less important, etc.

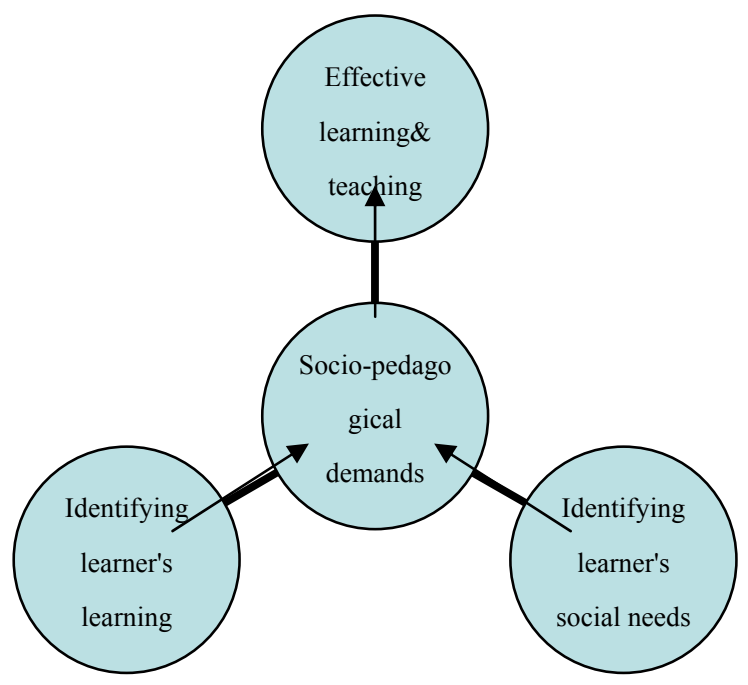

Figure 1. Intertwining learner's pedagogical and social needs produce effective learning

\section{Appendix 1. The Questionnaire}

Towards a Classroom-centered approach to L2 Teaching in the Palestinian Context

Section 1:

Gender: $\quad$ M

$\mathrm{F}$

Post title

University:

Your learners' level : All levels

Average number of students in each class:

Teaching experience: years

Academic year: 
Section 2: Respond to each point by adding a tick $(\sqrt{ })$ next to the item that applies to you:

\begin{tabular}{|c|c|c|c|c|}
\hline No. & Item & $\underset{8}{\stackrel{8}{8}}$ & $\begin{array}{l}\text { ZZ } \\
\text { o } \\
\text { 을. } \\
\text { ․․․ }\end{array}$ & 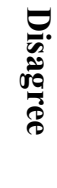 \\
\hline 1 & Humour is an essential part of my classroom teaching techniques. & & & \\
\hline 2 & My learners' social demands come second priority & & & \\
\hline 3 & My classroom physical setting is my first priority in teaching. & & & \\
\hline 4 & I always manage to identify my learners' learning needs. & & & \\
\hline 5 & My learners have identical cultural background. & & & \\
\hline 6 & $\begin{array}{l}\text { Meeting my learners' pedagogical needs is my ultimate goal of } \\
\text { teaching. }\end{array}$ & & & \\
\hline 7 & I consider each of my classes as one unit. & & & \\
\hline 8 & $\begin{array}{l}\text { I can easily explain why I feel relaxed when teaching certain } \\
\text { classes. }\end{array}$ & & & \\
\hline 9 & $\begin{array}{l}\text { I don't have the same feeling when I teach different classes with } \\
\text { the same level and syllabus. }\end{array}$ & & & \\
\hline 10 & Creating a homelike setting in my classroom is difficult. & & & \\
\hline 11 & Some of my classes are pedagogically frustrating. & & & \\
\hline 12 & I follow different teaching approaches for similar classes. & & & \\
\hline 13 & $\begin{array}{l}\text { Meeting my learners' social demands help me overcome teaching } \\
\text { obstacles. }\end{array}$ & & & \\
\hline
\end{tabular}

Section 3: As an EFL teacher, rank the following concepts in terms of importance to you when you teach: (no. 1 is the most important, 2 is less important, etc)

Classroom physical environment:

Class social setting:

Class pedagogical setting

Classroom cultural background

\section{Appendix 2. Questionnaire results: 8 Teachers}

Section 1:

Gender: $\quad$ M 7

F_8

Post title:

8 teachers 7TAs

University:

Your learners' level: All levels

Average number of students in each class:

Teaching experience: _1- 25 years .

Academic year: $2010 / 2011$ 
Section 2: Respond to each point by adding a tick $(\sqrt{ })$ next to the item that applies to you:

\begin{tabular}{|l|l|l|l|l|}
\hline No. & & \multicolumn{1}{|c|}{ Item } & & \\
& & & \\
\hline 1 & Humour is an essential part of my classroom teaching techniques. & 6 & & 2 \\
\hline 2 & My learners' social demands come second priority & 1 & 2 & 5 \\
\hline 3 & My classroom physical setting is my first priority in teaching. & 2 & & 6 \\
\hline 4 & I always manage to identify my learners' learning needs. & 5 & 3 & \\
\hline 5 & My learners have identical cultural background. & 1 & 2 & 5 \\
\hline 6 & Meeting my learners' pedagogical needs is my ultimate goal of teaching. & 5 & 1 & 2 \\
\hline 7 & I consider each of my classes as one unit. & 3 & 1 & 4 \\
\hline 8 & I can easily explain why I feel relaxed when teaching certain classes. & 6 & & 2 \\
\hline 9 & $\begin{array}{l}\text { I don't have the same feeling when I teach different classes with the same } \\
\text { level and syllabus. }\end{array}$ & 6 & 1 & 1 \\
\hline 10 & Creating a homelike setting in my classroom is difficult. & 4 & 1 & 3 \\
\hline 11 & Some of my classes are pedagogically frustrating. & 4 & 2 & 2 \\
\hline 12 & I follow different teaching approaches for similar classes. & 7 & 1 \\
\hline 13 & $\begin{array}{l}\text { Meeting my learners' social demands help me overcome teaching } \\
\text { obstacles. }\end{array}$ & 5 & 3 & \\
\hline $3:$ As & an EFL tacher & \\
\hline
\end{tabular}

Section 3: As an EFL teacher, rank the following concepts in terms of importance to you when you teach: (no. 1 is the most important, 2 is less important, etc)

Classroom physical environment: 34344431

Class social setting: 42431313

Class pedagogical setting 13112122

Classroom cultural background: 21223244

\section{Appendix 3. Questionnaire Results: 7 Teacher Assistants}

\section{Questionnaire Results: 7 TAs}

Section 1:

Gender: $\quad$ M 7

Post title: 8 teachers 7TAs

University:

Your learners' level: All levels

Average number of students in each class:

Teaching experience:_1- 25 years .

Academic year: 2010/2011 
Section 2: Respond to each point by adding a tick $(\sqrt{ })$ next to the item that applies to you:

\begin{tabular}{|c|c|c|c|c|}
\hline No. & Item & $\frac{8}{8}$ & $\begin{array}{l}\text { Ż } \\
\text { 을. } \\
\text { ․ㅡㄹ. }\end{array}$ & 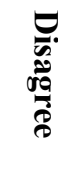 \\
\hline 1 & $\begin{array}{l}\text { Humour is an essential part of my classroom teaching } \\
\text { techniques. }\end{array}$ & 6 & 1 & \\
\hline 2 & My learners' social demands come second priority & 3 & 3 & 1 \\
\hline 3 & My classroom physical setting is my first priority in teaching. & 4 & 3 & \\
\hline 4 & I always manage to identify my learners' learning needs. & 5 & 1 & 1 \\
\hline 5 & My learners have identical cultural background. & 1 & & 6 \\
\hline 6 & $\begin{array}{l}\text { Meeting my learners' pedagogical needs is my ultimate goal of } \\
\text { teaching. }\end{array}$ & 3 & 3 & 1 \\
\hline 7 & I consider each of my classes as one unit. & 4 & 1 & 2 \\
\hline 8 & $\begin{array}{l}\text { I can easily explain why I feel relaxed when teaching certain } \\
\text { classes. }\end{array}$ & 6 & & 1 \\
\hline 9 & $\begin{array}{l}\text { I don't have the same feeling when I teach different classes with } \\
\text { the same level and syllabus. }\end{array}$ & 4 & 1 & 2 \\
\hline 10 & Creating a homelike setting in my classroom is difficult. & 1 & 4 & 2 \\
\hline 11 & Some of my classes are pedagogically frustrating. & 7 & & \\
\hline 12 & I follow different teaching approaches for similar classes. & 6 & & 1 \\
\hline 13 & $\begin{array}{l}\text { Meeting my learners' social demands help me overcome } \\
\text { teaching obstacles. }\end{array}$ & 2 & 5 & \\
\hline
\end{tabular}

Section 3: As an EFL teacher, rank the following concepts in terms of importance to you when you teach: (no. 1 is the most important, 2 is less important, etc)

Classroom physical environment: 14441332

Class social setting: 3324124

Class pedagogical setting: 1111124

Classroom cultural background: 2223334

\section{Appendix 4. Questionnaire All respondents Percentage}

\section{Section 1:}

Gender:

Post title: 8 teachers 7TAs

University:

Your learners' level: All levels

Average number of students in each class:

Teaching experience:_1- 25 years .

Academic year: $2010 / 2011$ 
Section 2: Respond to each point by adding a tick $(\sqrt{ })$ next to the item that applies to you:

\begin{tabular}{|c|c|c|c|c|}
\hline No. & Item & $\underset{8}{\overrightarrow{0}}$ & $\begin{array}{l}z \\
z \\
\text { zo } \\
\text { o. } \\
\text { o. }\end{array}$ & 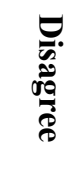 \\
\hline 1 & $\begin{array}{l}\text { Humour is an essential part of my classroom teaching } \\
\text { techniques. }\end{array}$ & 80.0 & 6.7 & 13.3 \\
\hline 2 & My learners' social demands come second priority & 26.7 & 33.3 & 40.0 \\
\hline 3 & $\begin{array}{l}\text { My classroom physical setting is my first priority in } \\
\text { teaching. }\end{array}$ & 40.0 & 20.0 & 40.0 \\
\hline 4 & I always manage to identify my learners' learning needs. & 73.3 & 26.7 & 0.0 \\
\hline 5 & My learners have identical cultural background. & 13.3 & 13.3 & 86.7 \\
\hline 6 & $\begin{array}{l}\text { Meeting my learners' pedagogical needs is my ultimate goal } \\
\text { of teaching. }\end{array}$ & 53.3 & 26.7 & 20.0 \\
\hline 7 & I consider each of my classes as one unit. & 46.7 & 13.3 & 40.0 \\
\hline 8 & $\begin{array}{l}\text { I can easily explain why I feel relaxed when teaching } \\
\text { certain classes. }\end{array}$ & 73.3 & 0.0 & 26.7 \\
\hline 9 & $\begin{array}{l}\text { I don't have the same feeling when I teach different classes } \\
\text { with the same level and syllabus. }\end{array}$ & 66.7 & 13.3 & 20.0 \\
\hline 10 & Creating a homelike setting in my classroom is difficult. & 33.3 & 33.3 & 33.3 \\
\hline 11 & Some of my classes are pedagogically frustrating. & 73.3 & 13.3 & 13.3 \\
\hline 12 & I follow different teaching approaches for similar classes. & 86.7 & 0.0 & 13.3 \\
\hline 13 & $\begin{array}{l}\text { Meeting my learners' social demands help me overcome } \\
\text { teaching obstacles. }\end{array}$ & 46.7 & 53.3 & 0.0 \\
\hline
\end{tabular}

Section 3: As an EFL teacher, rank the following concepts in terms of importance to you when you teach: (no. 1 is the most important, 2 is less important, etc)

Classroom physical environment: 34344431--1444132

Class social setting: 42431313--3324124

Class pedagogical setting13112122--1111124

Classroom cultural background: 21223244--2223334

\section{Appendix 5. Questionnaire section 3: Ranking items in terms of importance}

Table 2 (questionnaire section 3) Ranking items in terms of importance

\begin{tabular}{|l|l|l|l|l|}
\hline Item & $\begin{array}{l}\text { Rank } \\
\mathbf{1}\end{array}$ & $\begin{array}{l}\text { Rank } \\
\mathbf{2}\end{array}$ & $\begin{array}{l}\text { Rank } \\
\mathbf{3}\end{array}$ & $\begin{array}{l}\text { Rank } \\
\mathbf{4}\end{array}$ \\
\hline Class physical environment & 3 & 1 & 4 & 7 \\
\hline Class social setting & 3 & 3 & 5 & 4 \\
\hline Class pedagogical setting & 9 & 4 & 1 & 1 \\
\hline Class cultural background & 1 & 7 & 4 & 3 \\
\hline
\end{tabular}

